Reviu Akuntansi dan Bisnis Indonesia, Vol. 1 No. 2, Hlm: 131-143, Desember 2017

Website: http://journal.umy.ac.id/index.php/rab

\title{
Analisis Faktor-Faktor yang Mempengaruhi tingkat Underpricing Saham pada saat Initial Public Offering (IPO) (Studi Empiris pada Perusahaan yang Melakukan Penawaran Umum Perdana di Bursa Efek Indonesia Periode 2012-2016)
}

\author{
Idka Setia Ningrum; Harjanti Widiastuti \\ Program Studi Akuntansi Univeritas Muhammadiyah Yogyakarta.
}

I N F O A R T I K E L

Kata Kunci:

underpricing, underwriter

reputation, shareoffering

percentage, type of

industry, intellectual capital

disclosure

Jenis Artikel:

Penelitian Empiris

Correspondence:

widyas@umy.ac.id

\section{ABSTRAK}

Penelitian ini bertujuan untuk mengetahui faktor-faktor yang mempengaruhi tingkat underpricing saham pada penawaran umum perdana. Penelitian ini menggunakan variabel independen reputasi underwriter, persentase penawaran saham, jenis industri dan pengungkapan modal intelektual dengan leverage dan ukuran perusahaan sebagai variabel kontrol. Populasi yang digunakan dalam penelitian ini adalah semua perusahaan yang melakukan penawaran umum perdana (IPO) di Bursa Efek Indonesia periode 2012-2016. Pengambilan sampel penelitian dengan menggunakan metode purposive sampling dengan perolehan sampel sebanyak 71 perusahaan. Metode analisis yang digunakan dalam penelitian ini adalah analisis regresi linier berganda. Hasil penelitian menunjukkan bahwa reputasi underwriter, persentase penawaran saham dan jenis industri tidak berpengaruh terhadap underpricing. Sedangkan pengungkapan modal intelektual berpengaruh negatif terhadap underpricing. Variabel kontrol seperti leverage dan ukuran perusahaan tidak berpengaruh pada underpricing.

(C) 2019RAB. Published by Universitas Muhammadiyah Yogyakarta

\section{PENDAHULUAN}

Pertumbuhan ekonomi global yang semakin berkembang pesat membuat perusahaan harus mampu bertahan dan bersaing dalam dunia bisnis. Perusahaan dituntut untuk dapat menyediakan kebutuhan modal, sehingga dengan modal yang tersedia perusahaan akan mampu mengembangkan dan mempertahankan kelangsungan hidup usahanya. Pasar modal merupakan salah satu sarana yang mampu mendukung perusahaan dalam memenuhi kebutuhan keuangan dan untuk menambah modal yang dibutuhkan (Prawesti dan Indrasari, 2014). Penerbitan saham di pasar modal merupakan bentuk aktivitas yang dapat dilakukan perusahaan dalam usahanya untuk memperoleh pendanaan tersebut. Penerbitan saham perusahaan dapat dimulai dengan melakukan pencatatan saham perdana atau yang biasa disebut dengan Initial Public Offering (IPO) (Gunarsih dkk., 2014).

Initial Public Offering (IPO) merupakan suatu kegiatan penawaran saham yang untuk pertama kalinya dilakukan perusahaan di pasar perdana (Fitriani, 2012). Fenomena yang tidak dapat dipisahkan dan masih sering terjadi pada saat perusahaan melakukan IPO, yaitu 
underpricing. Underpricing adalah sebuah fenomena di mana harga saham di pasar perdana lebih rendah jika dibandingkan dengan harga saham yang berada di pasar sekunder. Di Indonesia sendiri dalam rentang waktu antara tahun 2012-2016 dari 107 perusahaan yang melakukan penawaran umum perdana terdapat 82 perusahaan terindikasi underpricing, 18 perusahaan mengalami overpricing dan sisanya sebanyak 7 perusahaan mengalami truepricing.Dari pernyataan di atas, dapat disimpulkan bahwa fenomena underpricing dari tahun ke tahun pada saat perusahaan melakukan IPO masih tergolong tinggi.

Fenomena underpricing dapat terjadi karena adanya suatu asimetri informasi. Asimetri informasi yang terjadi dapat mengakibatkan informasi tidak menyebar secara sempurna dan berakibat kepada ketidakmampuan investor dalam memprediksi keadaan perusahaan di masa mendatang. Penerbitan prospektus yang dilakukan oleh perusahaan dapat meminimalkan adanya asimetri informasi. Prospektus perusahaan berisikan sejumlah informasi baik yang bersifat keuangan maupun non keuangan dari perusahaan bersangkutan yang dapat digunakan untuk mengetahui faktor-faktor apa saja yang dapat mempengaruhi tingkat underpricing saham. Informasi tersebut dapat membantu investor dalam setiap pengambilan keputusan berkaitan dengan risiko nilai saham yang ditawarkan perusahaan (Kim et al., 1995).

\section{TINJAUAN LITERATURDAN PERUMUSAN HIPOTESIS}

\section{Teori Keagenan}

Teori keagenan (agency theory) merupakan suatu kontrak atau hubungan antara principal dengan agent. Asumsi dalam teori agensi adalah bahwa setiap individu memiliki motivasi yang tinggi akan kepentingan terhadap dirinya sendiri yang berdampak pada timbulnya konflik kepentingan di antara principal dengan agent (Anthony dan Govindarajan, 2005). Asimetri informasi dapat terjadi karena perbedaan gap di antara investor yang memiliki banyak informasi dengan investor yang kurang atau bahkan tidak memiliki informasi mengenai prospek serta kondisi perusahaan di masa depan (Gao et al., 2008). Semakin besar tingkat asimetri informasi yang terjadi, maka akan berdampak pada ketidakpastian bagi perusahaan di masa depan, sehingga underpricing yang terjadi juga akan semakin tinggi (Beatty dan Ritter, 1986).

\section{Teori Signaling}

Teori Signalling menyatakan bahwa asimetri informasi yang terjadi antara pihak-pihak yang berkepentingan dapat dikurangi yaitu dengan cara memberikan signal informasi dari salah satu pihak kepada pihak lain (Morris, 1987). Leland dan Pyle (1977) menjelaskan bahwa signal merupakan suatu tindakan untuk mengkomunikasikan informasi yang dilakukan oleh pemilik lama kepada para investor potensialnya. Pemilik lama termotivasi untuk dapat melakukan pengungkapan informasi privat perusahaan secara sukarela dengan alasan bahwa informasi yang diberikan dapat diinterpretasikan dan ditangkap menjadi sebuah signal positif mengenai penilaian terhadap kinerja perusahaan yang untuk selanjutnya dapat mengurangi adanya asimetri informasi yang berimplikasi pada semakin kecilnya tingkat ketidakpastian di masa mendatang. Semakin kecil tingkat ketidakpastian di masa depan, maka tingkat underpricing yang terjadi juga akan semakin rendah.

\section{Pengaruh Reputasi Underwriter Terhadap Underpricing}

Besar dan kecilnya suatu ukuran perusahaan akan mempengaruhi besarnya agency cost yang harus dikeluarkan. Perusahaan yang besar diikuti dengan agency cost yang besar, Adanya praktik IFR sebagai salah satu upaya dalam menurunkan agency cost yang dikeluarkan oleh perusahaan. Penelitian terdahulu oleh Kartika dan Puspa (2013), Ramadhan (2014), Pranoto 
(2015) menyatakan adanya pengaruh ukuran perusahaan terhadap pengungkapan IFR. Maka dari itu, hipotesis yang dapat diturunkan sebagai berikut:

\section{$\boldsymbol{H}_{t} \quad$ : Reputasi underwriter berpengaruh negatif terhadap underpricing.}

\section{Pengaruh Persentase Penawaran Saham Terhadap Underpricing}

Persentase saham yang ditawarkan ke publik menggambarkan informasi privat yang dimiliki perusahaan. Semakin besar persentase saham yang ditawarkan ke publik dan semakin besar pula tingkat ketidakpastian perusahaan di masa mendatang, maka harga saham pada saat IPO yang telah menjadi kesepakatan antara underwriter dengan perusahaan juga akan menjadi rendah. Hal tersebut dikarenakan underwriter berusaha untuk memperkecil setiap risiko yang mungkin terjadi apabila saham tidak habis terjual, sehingga apabila harga saham saat penawaran umum perdana relatif rendah, maka akan berakibat pada semakin besarnya tingkat underpricing yang terjadi (Maya, 2013).

Retnowati (2013) menyatakan bahwa persentase saham yang ditawarkan menunjukkan besarnya bagian dari total modal disetor yang dapat dimiliki oleh publik. Secara umum apabila bagian saham yang ditawarkan semakin besar maka dapat berdampak pada semakin besarnya potensi untuk likuidnya perdagangan saham yang ada di bursa, namun sebaliknya informasi privat yang dimiliki perusahaan akan semakin sedikit. Hasil penelitian tersebut didukung dengan penelitian Lestari (2015) dan Maya (2013). Berdasarkan penjelasan yang telah diuraikan di atas, maka peneliti menurunkan hipotesis sebagai berikut:

\section{$\boldsymbol{H}_{2} \quad$ : Persentase penawaran saham berpengaruh positif terhadap underpricing.}

\section{Pengaruh Jenis Industri Terhadap Underpricing}

Variabel jenis industri dapat saja memberikan pengaruh terhadap tingkat underpricing, hal tersebut dapat dikarenakan setiap jenis industri memiliki karakteristik masing-masing yang berbeda antara satu dengan yang lainnya dan berakibat pada perbedaan risiko yang dihadapi untuk setiap jenis industri. Perbedaan risiko tersebut dapat memberikan tingkat keuntungan yang diharapkan oleh para investor untuk setiap jenis industri yang berbeda. Sehingga underpricing yang terjadi untuk setiap jenis industri juga akan berbeda (Pahlevi, 2014).

Jenis industri yang masuk dalam kategori high profile merupakan industri dengan consumer visibility, tingkat risiko politik serta tingkat kompetisi yang lebih tinggi, sedangkan untuk kategori low profile yaitu industri dengan consumer visibility serta tingkat kompetisi yang relatif lebih rendah (Roberts, 1992). Industri dengan tingkat keunggulan kompetitif yang tinggi dan kinerja perusahaan yang baik akan mampu memberikan peningkatan nilai bagi perusahaan di mata investor, dengan begitu asimetri informasi yang terjadi menjadi semakin kecil dan berdampak pada semakin kecilnya tingkat underpricing (Pahlevi, 2014).

Yolana dan Martani (2005) serta Lestari (2015) menunjukkan bahwa jenis industri berpengaruh negatif terhadap underpricing. Perusahaan dengan jenis industri barang konsumen mempunyai tingkat underpricing yang lebih rendah bila dibandingkan dengan jenis industri lainnya. Barang konsumen sendiri merupakan barang yang dikonsumsi untuk kepentingan konsumen akhir bukan untuk tujuan bisnis, yang dalam hal ini dikategorikan ke dalam jenis industri high profile. Berdasarkan penjelasan yang telah diuraikan di atas, maka peneliti menurunkan hipotesis sebagai berikut:

$\boldsymbol{H}_{3} \quad$ :Jenis industri high profile berpengaruh negatif terhadap underpricing. 


\section{Pengaruh Pengungkapan Modal Intelektual Terhadap Underpricing}

Teori signalling menjelaskan bahwa pengungkapan modal intelektual merupakan signal positif bagi para pelaku pasar yaitu para investor. Signal positif tersebut dapat berupa banyaknya modal intelektual yang dimiliki oleh suatu perusahaan. Semakin banyak modal intelektual yang dimilki oleh perusahaan, maka akan berdampak pada semakin meningkatnya keunggulan kompetitif dan kemampuan bersaing dari perusahaan itu sendiri. Ketika investor dapat menginterprestasikan signal tersebut dengan baik, maka informasi yang diterima juga akan semakin lebih banyak sehingga nilai perusahaan akan meningkat di mata investor, dengan demikian tingkat underpricing yang terjadi akan semakin rendah (Kurniawan, 2014).

Gunarsih, dkk (2014) menyatakan bahwa semakin tinggi modal intelektual yang diungkapkan maka underpricing yang terjadi akan semakin rendah. Hasil tersebut mendukung teori signalling, di mana asimetri informasi dapat dikurang dengan pemberian signal informasi kepada pihak lain mengenai kualitas dari perusahaan. Pengungkapan modal intelektual merupakan sumber informasi yang penting bagi investor dan kreditor karena membuat laporan keuangan menjadi lebih relevan dan reliabel dalam memprediksi kinerja keuangan perusahaan di masa mendatang. Hal tersebut menunjukkan bahwa investor mulai mempertimbangkan dan memperhatikan pengungkapan modal intelektual sebagai sarana dalam pengambilan keputusan untuk pembelian saham perdana. Hasil penelitian tersebut didukung dengan penelitian Kurniawan (2014) dan Gunawan (2016). Berdasarkan penjelasan yang telah diuraikan di atas, maka peneliti menurunkan hipotesis sebagai berikut:

\section{$\boldsymbol{H}_{\text {*a }} \quad$ : Leverage berpengaruh positif terhadap pengungkapan IFR di Indonesia. \\ $\boldsymbol{H}_{4}$ : Pengungkapan modal intelektual berpengaruh negatif terhadap underpricing.}

\section{METODE PENELITIAN}

Penelitian ini menggunakan sampel pada seluruh perusahaan yang melakukan penawaran umum perdana di Bursa Efek Indonesia (BEI) selama periode 2012-2016. Sumber data yang digunakan adalah data sekunder, yaitu menggunakan data dari setiap laporan keuangan dan prospectus perusahaan. Teknik pengambilan sampel adalah purposive sampling dengan kriteria, antara lain (1) Perusahaan yang melakukan penawaran umum perdana (IPO) periode 2012-2016 di Bursa Efek Indonesia, (2) Saat penawaran perdana di pasar sekunder, perusahaan tersebut mengalami underpricing; (3) Perusahaan yang melakukan penawaran saham perdana (IPO) mempunyai data lengkap berkaitan dengan setiap variabel yang digunakan di dalam penelitian. Metode yang dipakai untuk mengumpulkan data penelitian adalah metode dokumentasi, yaitu dengan melihat laporan keuangan dan prospectus perusahaan yang dijadikan sampel penelitian yang diperoleh dari www.idx.co.id.

Teknik pengolahan data yang digunakan dalam penelitian ini menggunakan uji statistik deskriptif yang digunakan dalam mendiskripsikan variabel-variabel dalam penelitian dan uji asumsi klasik yang meliputi uji normalitas, uji multikolinearitas, uji heteroskedastisitas, dan uji autokorelasi. Analisis data dalam pengujian hipotesis menggunakan analisis regresi linier berganda yang meliputi uji koefisien determinasi, uji signifikansi simultan, dan uji signifikan parameter individual. Model regresi yang digunakan didalam penelitian adalah sebagai berikut:

$$
U N D_{i, t}=\alpha+\beta_{1} U D W_{i, t}+\beta_{2} \text { OFFER }_{i, t}+\beta_{3} I E_{i, t}+\beta_{4} I C D_{i, t}+\beta_{5} L E V_{t-1}+\beta_{6} S_{Z I Z E_{i, t}}+e
$$

Keterangan:

$\alpha=$ Konstan

$\beta=$ Koefisien Regresi

$e \quad=$ Residual Error 
$U N D_{i, t}=$ Tingkat underpricing pada perusahaan i saat $I P O$

$U D W_{i, t}=$ Reputasi Underwriter perusahaan i saat IPO

OFFER $_{i, t} \quad=$ Persentase Penawaran Saham perusahaan i saat IPO

$I E_{i}=$ Jenis Industri perusahaan $\mathrm{i}$

$I C D_{i, t}=$ Tingkat Pengungkapan Modal Intelektual perusahaan i saat IPO

$L E V_{t-1}=$ Rasio Hutang satu tahun sebelum IPO perusahaan $\mathrm{i}$

$S I Z E_{i, t}=$ Ukuran perusahaan i saat IPO

Tabel 1 Pengukuran Variabel

\begin{tabular}{|c|c|c|}
\hline Variabel & Pengukuran & Keterangan \\
\hline Underpricing & $I R=\frac{P_{t 1}-P_{t 0}}{P_{t 0}} \times 100 \%$ & $\begin{array}{l}\text { IR = Initial Return } \\
\mathrm{P}_{10}=\text { Harga Penawaran } \\
\text { Perdana } \\
\mathrm{P}_{1 \mathrm{u}}=\text { Harga Saham } \\
\text { Penutupan di Pasar } \\
\text { Sekunder }\end{array}$ \\
\hline $\begin{array}{l}\text { Reputasi } \\
\text { Underwriter }\end{array}$ & $\begin{array}{l}\text { Menggunakan variabel dummy } \\
\text { (10 most active brokerage by volume dalam IDX Fact Book) }\end{array}$ & $\begin{array}{l}\text { Nilai 1: } \\
\text { Nilai } \quad 0 \text { : } \quad \text { Reputasi tinggi } \\
\text { rendah }\end{array}$ \\
\hline $\begin{array}{l}\text { Persentase } \\
\text { Penawaran } \\
\text { Saham }\end{array}$ & $\begin{array}{l}\text { OFFER } \\
=\frac{\text { Jumlah saham yang ditawarkan ke publik }}{\text { Jumlah saham beredar }} \times 100 \%\end{array}$ & \\
\hline Jenis Industri & Menggunakan variabel dummy & $\begin{array}{l}\text { Nilai 1: High profile } \\
\text { Nilai 0: Low profile }\end{array}$ \\
\hline $\begin{array}{l}\text { Pengungkapan } \\
\text { Modal } \\
\text { Intelektual } \\
\text { Leverage }\end{array}$ & $\begin{array}{l}\text { ICD } \\
=\frac{\text { Jumlah item pertanyaan yang diungkapkan }}{81} \times 100 \% \\
\text { DER }_{t-1}=\frac{\text { Hutang }_{t-1}}{\text { Ekuitas }_{t-1}}\end{array}$ & \\
\hline $\begin{array}{l}\text { Ukuran } \\
\text { Perusahaan }\end{array}$ & $S I Z E=\operatorname{Ln}($ Total Asset $)$ & \\
\hline
\end{tabular}

\section{HASIL DAN PEMBAHASAN}

\section{Gambaran Umum Obyek Penelitian}

Obyek yang digunakan dalam penelitian ini adalah perusahaan yang melakukan penawaran umum perdana di Bursa Efek Indonesia periode 2012-2016. Perincian pengambilan sampel tersebut dapat dilihat pada Tabel 2 berikut ini:

Tabel 2 Sampel Penelitian

\begin{tabular}{|c|c|c|}
\hline No. & Keterangan & Jumlah \\
\hline 1. & $\begin{array}{l}\text { Perusahaan yang melakukan penawaran umum perdana di BEI periode } \\
2012-2016\end{array}$ & 107 \\
\hline 2. & Perusahaan yang mengalami overpricing & (18) \\
\hline 3. & Perusahaan yang mengalami truepricing & (7) \\
\hline & $\begin{array}{l}\text { Perusahaan dengan data yang tidak lengkap berkaitan dengan setiap } \\
\text { variabel yang digunakan di dalam penelitian. }\end{array}$ & (3) \\
\hline & Sampel yang mengalami outlier & (8) \\
\hline \multirow{2}{*}{\multicolumn{2}{|c|}{ Perusahaan yang terpilih sebagai sampel }} & 71 \\
\hline & & 71 \\
\hline
\end{tabular}




\section{Uji Analisis Statistik Deskriptif}

Hasil pengujian statistik deskriptif terhadap variabel-variabel yang digunakan di dalam penelitian dapat dilihat pada Tabel 3 berikut:

Tabel 3 Hasil Uji Statistik Deskriptif

\begin{tabular}{lrrrrr}
\hline Variabel & N & \multicolumn{1}{c}{ Minimum } & \multicolumn{1}{c}{ Maximum } & Mean & \multicolumn{1}{c}{ Std. Deviation } \\
\hline UDW & 71 & 0 & 1 &, 48 &, 503 \\
OFFER & 71 &, 02 &, 53 &, 2244 &, 10181 \\
IE & 71 & 0 & 1 &, 38 &, 489 \\
ICD & 71 &, 14 &, 42 &, 2731 &, 06720 \\
LEV & 71 &, 12 & 8,79 & 2,6051 & 2,23679 \\
SIZE & 71 & 126.998 .196 .000 & 24.846 .516 .000 .000 & $2.158 .628 .117 .621,97$ & $3.192 .156 .725 .943,667$ \\
UND & 71 &, 00 &, 70 &, 2874 &, 24776 \\
\hline
\end{tabular}

\section{Uji Asumsi Klasik}

\section{Uji Normalitas}

Hasil uji normalitas disajikan dalam tabel berikut:

Tabel 4 One-Sample Kolmogorov-Smirnov Test

\begin{tabular}{lr}
\hline & Unstandardized Residual \\
\hline N & 71 \\
Kolmogorov-Smirnov Z & 0,674 \\
Asymp. Sig. (2-tailed) & 0,754 \\
\hline
\end{tabular}

Tabel 4 menunjukkan bahwa nilai Asymp. Sig. (2-tailed) dari seluruh data yang digunakan dalam penelitian adalah sebesar $0,754>0,05$. Hal ini menunjukkan bahwa keseluruhan data yang digunakan sebagai sampel dalam penelitian berdistribusi normal.

\section{Uji Multikolinearitas}

Hasil uji multikolinearitas adalah sebagai berikut:

Tabel 5 Hasil Uji Multikolinearitas

\begin{tabular}{cccc}
\hline Variabel & Tolerance & VIF & Keterangan \\
\hline UDW & 0,794 & 1,259 & Tidak terjadi multikolinearitas \\
OFFER & 0,919 & 1,088 & Tidak terjadi multikolinearitas \\
IE & 0,821 & 1,218 & Tidak terjadi multikolinearitas \\
ICD & 0,761 & 1,314 & Tidak terjadi multikolinearitas \\
LEV & 0,745 & 1,343 & Tidak terjadi multikolinearitas \\
SIZE & 0,776 & 1,288 & Tidak terjadi multikolinearitas \\
\hline
\end{tabular}

Berdasarkan Tabel 5 dapat diketahui bahwa dari semua variabel yang digunakan dalam penelitian memiliki nilai tolerance $>0,1$ dan nilai VIF $<10$. Sehingga, dapat disimpulkan bahwa model regresi tidak mengalami multikolinearitas.

\section{Uji Heteroskedastisitas}

Hasil uji heteroskedastisitas adalah sebagai berikut: 
Tabel 6 Hasil Uji Heteroskedastisitas

\begin{tabular}{ccc}
\hline Variabel & Sig. & Keterangan \\
\hline UDW & 0,907 & Tidak terjadi heteroskedastisitas \\
OFFER & 0,791 & Tidak terjadi heteroskedastisitas \\
IE & 0,220 & Tidak terjadi heteroskedastisitas \\
ICD & 0,140 & Tidak terjadi heteroskedastisitas \\
LEV & 0,353 & Tidak terjadi heteroskedastisitas \\
SIZE & 0,591 & Tidak terjadi heteroskedastisitas \\
\hline
\end{tabular}

Hasil pengujian menunjukkan bahwa dari keseluruhan variabel penelitian baik variabel independen maupun variabel kontrol terlihat bahwa nilai Sig. > 0,05 yang berarti bahwa model penelitian tidak mengalami heteroskedastisitas.

\section{Uji Autokorelasi}

Uji autokorelasi dalam penelitian ini menggunakan uji Durbin-Watson $\left(d_{w}\right.$ test $)$. Adapun hasil pengujian adalah sebagai berikut:

Tabel 7 Hasil Uji Autokorelasi

\begin{tabular}{cccc}
\hline $\mathbf{d U}$ & $\mathbf{d W}$ & 4-dU & Kesimpulan \\
\hline 1,7358 & 2,164 & 2,2642 & Tidak terjadi autokorelasi \\
\hline
\end{tabular}

Berdasarkan Tabel 7 dapat diketahui bahwa nilai Durbin-Watson (dW) adalah sebesar 2,164. Berdasarkan tabel Durbin-Watson (DW), nilai dU dengan $\mathrm{k}=4$ dan $\mathrm{n}=71$ adalah sebesar 1,7358, maka nila 4-dU diperoleh sebesar 2,2642, sehingga $1,7358<2,164<2,2642$. Dengan demikian dapat diambil kesimpulan bahwa model regresi penelitian tidak terjadi autokorelasi.

\section{Hasil Pengujian Hipotesis}

Hasil pengujian regresi linier berganda yang telah dilakukan tampak pada Tabel 8 sebagai berikut:

Tabel 8 Hasil Uji Regresi Linier Berganda

\begin{tabular}{|c|c|c|c|c|}
\hline & Unstandardize & & & \\
\hline Variabel & Coefficients & $\mathrm{t}_{\text {nitung }}$ & Sig & Kesimpulan \\
\hline & B & & & \\
\hline Konstanta & 2,196 & & & \\
\hline UDW & $-0,066$ & $-1,087$ & 0,281 & Ditolak \\
\hline OFFER & 0,028 & 0,099 & 0,921 & Ditolak \\
\hline IE & $-0,022$ & $-0,349$ & 0,728 & Ditolak \\
\hline ICD & $-0,959$ & $-2,053$ & 0,044 & Diterima \\
\hline LEV & 0,003 & 0,213 & 0,832 & Ditolak \\
\hline SIZE & $-0,058$ & $-1,988$ & 0,051 & Ditolak \\
\hline Variabel Dependen & UND & & & \\
\hline Adjusted $R^{2}$ & $: 0,144$ & & & \\
\hline$F_{\text {hitumg }}$ & $: 2,969$ & & & \\
\hline $\operatorname{Sig} \mathrm{F}$ & $: 0,013$ & & & \\
\hline
\end{tabular}

\section{Uji Koefisiensi Determinasi (Adjusted R')}

Berdasarkan Tabel 8 dapat diketahui bahwa nilai Adjusted $R^{2}$ sebesar 0,144 atau 14,4\%. Artinya, kemampuan variabel independen yaitu reputasi underwriter, persentase penawaran 
saham, jenis industri, dan pengungkapan modal intelektual serta variabel kontrol leverage dan ukuran perusahaan dalam menjelaskan variasi variabel dependen yaitu underpricing adalah sebesar 14,4\%, sedangkan sisanya 85,6\% dijelaskan oleh variabel lain yang tidak diteliti.

\section{Uji Signifikansi Simultan (Uji Statistik Nilai F)}

Berdasarkan Tabel 8 dapat dilihat bahwa model regresi memiliki nilai Sig F sebesar 0,013 < 0,05 yang berarti bahwa terdapat pengaruh secara bersama-sama antara variabel independen terhadap variabel dependen.

\section{Uji Signifikan Parameter Individual (Uji Statistik t)}

\section{Pengaruh Reputasi Underwriter Terhadap Underpricing}

Hasil pengujian hipotesis pertama pada Tabel 8 menunjukkan bahwa reputasi underwriter tidak berpengaruh terhadap underpricing. Sehingga, hipotesis yang menyatakan bahwa reputasi underwriter berpengaruh negatif terhadap underpricing ditolak, yang berarti bahwa reputasi underwriter belum mampu meminimalisir tingkat underpricing yang terjadi. Hasil tersebut sejalan dengan penelitian yang dilakukan oleh Aini (2013), Pahlevi (2014), Prawesti dan Indrasari (2014), Saputri (2016), Wahyusari (2013) yang mengungkapkan bahwa reputasi underwriter tidak berpengaruh terhadap underpricing. Namun hasil penelitian ini tidak sejalan dengan penelitian yang dilakukan oleh Ardhianto (2011), Gunarsih, dkk (2014), Junaeni dan Agustian (2013), Kristiantari (2013), Lestari (2015), Purwanto dan Mahyani (2016), Rastiti (2015), Risqi (2013) yang menunjukkan bahwa reputasi underwriter berpengaruh negatif terhadap underpricing.

Reputasi Underwriter yang tidak berpengaruh terhadap underpricing disebabkan karena adanya perbedaan pemeringkatan oleh lembaga penjamin emisi. Dalam penelitian ini pemeringkatan underwriter didasarkan pada 10 most active brockerage by volume yang tersedia dalam IDX Fact Book. Perbedaan tersebut dapat terjadi karena belum terdapatnya lembaga resmi yang memeringkatkan reputasi underwriter di Indonesia (Saputri, 2016). Selain itu tidak berpengaruhnya reputasi underwriter terhadap underpricing disebabkan oleh penggunaan underwriter dengan reputasi baik oleh perusahaan belum mampu memberikan sinyal positif bagi investor untuk dapat memperkirakan nilai sesungguhnya bagi perusahaan yang melakukan IPO (Aini, 2013).

Hasil tersebut mendukung teori persignalan di mana asimetri informasi dapat diminimalisir dengan cara salah satu pihak memberikan sinyal informasi kepada pihak lain mengenai kualitas dari perusahaan. Reputasi underwriter memberikan sinyal bagi investor dalam menilai kualitas dari perusahaan yang baik maupun yang buruk. Underwriter dengan reputasi baik merupakan sebuah sinyal positif bagi investor dalam menilai saham perusahaan yang berkualitas baik. Terdapat dua syarat suatu sinyal positif dapat menjadi efektif, yaitu sinyal tersebut harus mampu sampai dan dapat dipersepsikan dengan baik oleh calon investor serta sinyal tersebut tidak mudah ditiru oleh perusahaan berkualitas rendah. Sedangkan penggunaan underwriter dengan reputasi tinggi relatif lebih mudah ditiru oleh semua perusahaan, sehingga dalam hal ini investor sulit untuk dapat membedakan kualitas perusahaan yang baik dengan yang buruk jika hanya dari melihat underwriter yang berperan dalam melakukan penjaminan emisi pada saham IPO (Hartono, 2005).

\section{Pengaruh Persentase Penawaran Saham Terhadap Underpricing}

Persentase saham yang ditawarkan ke publik menggambarkan informasi privat yang dimiliki perusahaan. Semakin besar tingkat persentase saham yang ditawarkan ke publik maka ketidakpastian di masa mendatang juga akan semakin besar. Hal tersebut dikarenakan informasi privat yang dimiliki para pemegang saham lama akan semakin kecil, sehingga dapat berdampak 
pada semakin besarnya tingkat ketidakpastian yang ditanggung para pemegang saham baru (Pahlevi, 2014).

Berdasarkan hasil pengujian hipotesis kedua pada Tabel 8 menunjukkan bahwa persentase penawaran saham tidak berpengaruh terhadap underpricing. Sehingga, hipotesis yang menyatakan bahwa persentase penawaran saham berpengaruh positif terhadap underpricing ditolak. Hasil penelitian ini sejalan dengan penelitian yang dilakukan oleh Fitriani (2012), Pahlevi (2014), Rastiti (2015), Yasa (2008), Yustisia dan Roza (2012) yang menunjukkan bahwa persentase penawaran saham tidak berpengaruh terhadap underpricing. Namun hasil penelitian ini tidak sejalan dengan penelitian Lestari (2015), Retnowati (2013), Maya (2013) yang mengungkapkan bahwa persentase penawaran saham berpengaruh positif terhadap underpricing.

Tidak berpengaruhnya persentase penawaran saham ke publik terhadap underpricing dikarenakan bahwa rendahnya rata-rata saham yang ditawarkan kepada publik masih belum mampu menjelaskan prospek dan kondisi perusahaan di masa mendatang. Hasil tersebut mendukung teori asimetri informasi di mana asimetri informasi yang terjadi dapat mengakibatkan informasi tidak menyebar secara sempurna dan berakibat pada ketidakmampuan investor dalam memprediksi keadaan perusahaan di masa mendatang.

Hasil pengujian statistik deskriptif menunjukkan bahwa nilai rata-rata persentase penawaran saham adalah sebesar 22,44\%. Meskipun proporsi saham yang ditawarkan ke publik relatif rendah, hal tersebut belum mampu menyatakan informasi privat perusahaan dan penentuan nilai ketidakpastian return di masa yang akan datang. Hal tersebut juga mengindikasikan bahwa investor dalam melakukan pembelian saham yang ditawarkan ke publik bukan berorientasi pada jumlah lembar saham yang ditawarkan tetapi lebih kepada berapa nilai penawaran saham tersebut.

\section{Pengaruh Jenis Industri Terhadap Underpricing}

Jenis industri menggambarkan karakteristik dari setiap perusahaan yang beroperasi dalam dunia perindustrian. Jenis industri juga menunjukkan apakah perusahaan yang menjadi sampel tergolong sebagai high profile atau low profile. Jenis industri yang masuk dalam kategori high profile merupakan industri dengan consumer visibility, tingkat risiko politik serta tingkat kompetisi yang lebih tinggi, sedangkan untuk kategori low profile yaitu industri dengan consumer visibility serta tingkat kompetisi yang relatif lebih rendah (Roberts, 1992). Industri dengan tingkat keunggulan kompetitif yang tinggi dan kinerja perusahaan yang baik akan mampu memberikan peningkatan nilai bagi perusahaan di mata investor, dengan begitu asimetri informasi yang terjadi menjadi semakin kecil dan berdampak pada semakin kecilnya tingkat underpricing (Pahlevi, 2014).

Hasil pengujian hipotesis ketiga pada Tabel 8 menunjukkan bahwa jenis industri tidak berpengaruh terhadap underpricing. Sehingga, hipotesis yang menyatakan bahwa jenis industri high profile berpengaruh negatif terhadap underpricing ditolak, yang berarti bahwa jenis industri belum mampu meminimalkan terjadinya underpricing pada perusahaan yang melakukan IPO. Hasil tersebut sejalan dengan penelitian yang dilakukan oleh Kristiantari (2013), Pahlevi (2014), Prawesti dan Indrasari (2014) yang mengungkapkan bahwa jenis industri tidak berpengaruh terhadap underpricing. Namun hasil penelitian ini tidak sejalan dengan penelitian Lestari (2015) serta Yolana dan Martani (2005) yang menunjukkan bahwa jenis industri memiliki pengaruh negatif terhadap underpricing.

Jika dilihat pada Tabel 3 terlihat bahwa perusahaan dengan jenis industri high profile hanya sebanyak 38\% dari total keseluruhan perusahaan yang melakukan IPO. Tidak berpengaruhnya jenis industri terhadap tingkat underpricing diduga karena perusahaan yang melakukan penawaran umum perdananya lebih didominasi oleh perusahaan low profile dibanding dengan high profile, sehingga sinyal yang diterima oleh investor belum mampu diinteprestasikan dan ditangkap menjadi sinyal yang positif dalam menilai prospek dan kondisi perusahaan di masa yang akan datang dengan artian bahwa hasil penelitian belum dapat mendukung teori persignalan. Selain itu, dugaan penyebab lainnya adalah jika dilihat dari sudut pandang investor, mereka tidak membedakan jenis industri dalam melakukan investasi pada perusahaan yang melakukan IPO. 
Investor menganggap bahwa risiko dari setiap investasi yang dilakukan terdapat pada semua jenis industri, sehingga peluang untuk memperoleh keuntungan pun dapat saja dimiliki oleh semua jenis industri yang ada (Kristiantari, 2013).

\section{Pengaruh Pengungkapan Modal Intelektual Terhadap Underpricing}

Pengungkapan modal intelektual digunakan untuk mengukur aset tak berwujud yang dimiliki oleh suatu perusahaan di mana pengukurannya dilakukan dengan menggunakan itemitem pernyataan dalam enam komponen utama, antara lain: karyawan, pelanggan, teknologi informasi, proses, riset dan pengembangan $(\mathrm{R} \& \mathrm{D})$, dan juga pernyataan strategis (Bukh et al., 2004). Berdasarkan teori signalling, pengungkapan modal intelektual merupakan sebuah pengungkapan yang dapat mengurangi terjadinya asimetri informasi dan untuk selanjutnya digunakan oleh pelaku pasar khususnya investor dalam menilai dan memprediksi perusahaan di masa mendatang yang berujung pada berkurangnya tingkat underpricing yang terjadi (Martani, 2012).

Berdasarkan Tabel 8, variabel pengungkapan modal intelektual memiliki arah hubungan negatif dengan koefisien -0,959 dan probabilitas signifikansinya sebesar $0,044<0,05$. Hasil pengujian tersebut menunjukkan bahwa pengungkapan modal intelektual berpengaruh negatif terhadap underpricing. Sehingga, hipotesis yang menyatakan bahwa pengungkapan modal intelektual berpengaruh negatif terhadap underpricing diterima. Artinya, bahwa pengungkapan modal intelektual mampu meminimalkan terjadinya underpricing pada perusahaan yang melakukan IPO. Hasil tersebut sejalan dengan penelitian Gunarsih, dkk (2014), Gunawan (2016), Kurniawan (2014) yang menyatakan bahwa pengungkapan modal intelektual berpengaruh negatif terhadap underpricing. Namun hasil penelitian ini tidak sejalan dengan penelitian Ardhianto (2011), Saputri (2016), Satriawan (2016) yang menunjukkan bahwa pengungkapan modal intelektual tidak berpengaruh terhadap underpricing.

Hasil tersebut mendukung teori persignalan, yang menjelaskan bahwa asimetri informasi dapat dikurangi dengan cara salah satu pihak memberikan sinyal informasi kepada pihak lain yang dapat menggambarkan kualitas dari perusahaan. Pengungkapan modal intelektual dapat menjadi sumber informasi yang bermanfaat bagi pihak-pihak yang berkepentingan terhadap perusahaan dalam proses pembuatan keputusan, karena penyajian modal intelektual membuat laporan keuangan menjadi lebih relevan dan reliabel terutama dalam memprediksi kinerja keuangan perusahaan di masa mendatang yang sangat penting bagi para investor dan kreditor. Hal tersebut menunjukkan bahwa investor mulai mempertimbangkan pengungkapan modal intelektual sebagai salah satu hal penting yang perlu diperhatikan untuk setiap pengambilan keputusan dalam membeli saham perdana.

\section{Pengaruh Leverage dan Ukuran Perusahaan Terhadap Underpricing}

Leverage dan ukuran perusahaan sebagai variabel kontrol dalam penelitian ini tidak berpengaruh terhadap underpricing. Leverage dan ukuran perusahaan tidak dapat menjadi pedoman bahwa perusahaan di masa mendatang akan mampu memberikan return yang besar kepada para investor. Hal tersebut sejalan dengan penelitian Saputri (2016) yang menyatakan bahwa leverage dan ukuran perusahaan tidak berpengaruh terhadap underpricing.

Tingkat hutang suatu perusahaan yang tinggi merupakan bentuk sinyal negatif bagi pelaku pasar, salah satunya adalah underwriter. Dengan semakin tingginya tingkat hutang, maka dapat membuat underwriter melakukan penawaran di bawah harga yang telah ditetapkan perusahaan sehingga hal tersebut dapat menyebabkan terjadinya underpricing (Saputri, 2016). Ukuran perusahaan yang tidak berpengaruh terhadap underpricing menunjukkan bahwa investor tidak melihat ukuran perusahaan sebagai faktor utama dalam menilai risiko dan return dalam berinvestasi melainkan pada hal-hal lain yang berkaitan dengan risiko-risiko dalam neraca dan di luar neraca (Witjaksono, 2012). 


\section{KETERBATASAN PENELITIAN}

Keterbatasan dalam penelitian ini antara lain: Sampel yang digunakan dalam penelitian masih tergolong sedikit karena jumlah perusahaan yang melakukan penawaran umum perdana dari tahun ke tahun masih relatif sedikit. Masih terdapat banyak faktor lain di luar variabel penelitian yang berpengaruh terhadap underpricing dan diduga dapat mempengaruhi secara cepat keadaan di pasar modal, di mana faktor-faktor tersebut tidak diteliti dalam penelitian ini.

\section{KESIMPULAN}

Berdasarkan hasil analisis dan pengujian data, dapat disimpulkan pertama, hasil pengujian hipotesis pertama menunjukkan bahwa reputasi underwriter tidak berpengaruh terhadap underpricing. Kedua, hasil pengujian hipotesis kedua menunjukkan bahwa persentase penawaran saham tidak berpengaruh terhadap underpricing. Ketiga, hasil pengujian hipotesis ketiga menunjukkan bahwa jenis industri tidak berpengaruh terhadap underpricing. Keempat, hasil pengujian hipotesis keempat menunjukkan bahwa pengungkapan modal intelektual berpengaruh negatif terhadap underpricing. Kelima, hasil pengujian variabel kontrol yaitu leverage dan ukuran perusahaan tidak berpengaruh terhadap underpricing.

Oleh karena itu, penelitian selanjutnya diharapkan untuk: (a) mempertimbangkan untuk menambah variabel penelitian karena masih banyak faktor-faktor lain yang berkontribusi dalam memengaruhi terjadinya underpricing, seperti indikator kinerja keuangan yang mencakup profitabilitas, solvabilitas, maupun likuiditas perusahaan. (b) memperhatikan kondisi perekonomian secara global, seperti isu-isu ekonomi dan politik, sehingga diharapkan mampu menjadikan isu-isu ekonomi dan politik tersebut menjadi variabel tambahan dalam penelitian. (c) menggunakan pemeringkatan lain dalam mengukur variabel reputasi underwriter, seperti pemeringkatan underwriter teraktif oleh BAPEPAM yang digolongkan ke dalam kelompok The Big Ten.

\section{DAFTAR PUSTAKA}

Aini, S. N. (2013). Faktor-Faktor Yang Mempengaruhi Underpricing Saham Pada Perusahaan IPO di BEI Periode 2007-2011. Jurnal Ilmiah Manajemen, 1(1), 1-15.

Anthony \& Govindarajan. (2005). Management Control System. Jakarta: Salemba Empat.

Ardhianto, A. (2011). Pengaruh Pengungkapan Intellectual Capital dalam Prospektus Terhadap Tingkat Underpricing pada First Day Listing Date (Studi Empiris pada Perusahaan yang Melakukan Initial Public Offering di Bursa Efek Indonesia Periode 2005-2009). Skripsi.

Beatty, R.P., \& Ritter J.R., (1986). Investment Banking, Reputation, and The Underpricing of Initial Public Offering. Journal of Financial Economics 15, $213-232$.

Bukh, P.N., Nielsen, C., Gormsen, P., \& Mouritsen, J. (2004). Disclosure of information on intellectual capital in Danish IPO prospectuses. Accounting, Auditing \& Accountibility Journal, 18 (6), 713-723.

Fitriani, D. (2012). Analisis Faktor-faktor yang Mempengaruhi Underpricing Setelah IPO (Studi Kasus IPO Perusahaan Listing di Bursa Efek Indonesia periode 2005-2010). Skripsi. Universitas Diponegoro. Semarang.

Gao, H., Darroch, J., Mather, D \& MacGregor, A. (2008). Signaling Corporate Strategy in IPO Communication. Journal of Business Communication, 45(1), 3-30.

Gunarsih, T., Handayani, W., \& Wijayanti, L. E. (2014). Pengaruh Pengungkapan Intellectual Capital dan Kepemilikan Institusi Terhadap Underpricing pada Penawaran Umum Perdana. Jurnal EKOBIS, 15(1), 85-101. 
Gunawan, C. (2016). Pengaruh Pengungkapan Modal Intelektual Terhadap Underpricing Saham Perusahaan yang IPO di BEI Periode 2009-2014. Skripsi. Universitas Katolik Widya Mandala.

Hartono. (2005). Hubungan Teori Signalling dengan Underpricing Saham Perdana di Bursa Efek Jakarta. Jurnal Bisnis dan Manajemen. 5 (1), 35-50.

Junaeni, I., \& Agustian, R. (2013). Analisis Faktor-faktor yang Mempengaruhi Tingkat Underpricing Saham pada Perusahaan Yang Melakukan Initial Public Offering di BEI. Jurnal Ilmiah WIDYA, 1(1), 52-59.

Kim, J. B., Krinsky, I., \& Lee, J. (1995). The Aftermarket Performance of Initial Public Offerings in Korea. Pacific-Basin Finance Journal, 3, 429-448.

Kristiantari, I. D. A. (2013). Analisis Faktor-faktor yang Mempengaruhi Underpricing Saham pada Penawaran Saham Perdana di Bursa Efek Indonesia. Jurnal Ilmiah Akuntansi dan Humaika, 2(2), 785-811.

Kurniawan, W. W. (2014). Pengaruh Pengungkapan Intellectual Capital dalam Prospektus Terhadap Underpricing Saham (Studi pada Perusahaan yang Melakukan Initial Public Offering di BEI Periode 2007-2012). Diponegoro Journal of Accounting, 3(2), 1-14.

Leland, H. E. \& D. H. Pyle. (1977). Informational Asymetries, Financial Structure, and Financial Intermediation. The Journal of Finance 32 (2): 371-387.

Lestari, A. H. (2015). Saham Pada Penawaran Umum Perdana di BEI Periode 2012-2014 (Studi pada Perusahaan yang Melaksanakan IPO di Bursa Efek Indonesia Periode 2012-2014). Jurnal Administrasi Bisnis, 25(1), 1-9.

Martani, D. (2003). Pengaruh Informasi Selama Proses Penawaran Terhadap Initial Return Perusahaan yang Listing di Bursa Efek Jakarta dari Tahun 1990-2000. Simposium Nasional Akuntansi VI. 1-15.

Maya, R. (2013). Pengaruh Kondisi Pasar, Persentase Saham yang Ditawarkan, Financial Leverage, dan Profitabilitas Terhadap Underpricing Saham yang IPO di BEI Periode 2007-2011. Skripsi. Universitas Negeri Padang.

Morris, R.D. (1987). Signalling, Agency Theory and Accounting Policy Choice. Accounting and Business Research, 18 (69), 47-56.

Pahlevi, R. W. (2014). Analisis Faktor-faktor yang Mempengaruhi Underpricing Saham pada Penawaran Saham Perdana di Bursa Efek Indonesia. Jurnal Siasat Bisnis, 18(2), 219-232.

Prawesti, L., \& Indrasari, A. (2014). Informasi Akuntansi dan Non Akuntansi Terhadap Initial Return Saham. Jurnal Akuntansi dan Investasi, 15(1), 19-27.

Purwanto, \& Esti Mahyani, R. (2016). Faktor-faktor Penyebab IPO Underpricing di Indonesia. Fokus Manajerial, 14(1), 67-76.

Rastiti, F. (2015). Studi Empiris Tingkat Underpricing pada Initial Public Offering. Jurnal Akuntansi Multiparadigma, 6(3), 493-503.

Retnowati, E. (2013). Penyebab Underpricing pada Penawaran Saham Perdana di Indonesia. Accounting Analysis Journal, 2(2), 182-190.

Risqi, I. A. (2013). Analisis Faktor-faktor Determinan Underpricing ketika Initial Public Offering (IPO) dan Pengaruhnya Terhadap Earnings Persistence (Studi Empiris pada Perusahaan yang Go Public Tahun 2007-2011). Skripsi.

Roberts, R.W. (1992), Determinants of corporate social responsibility disclosure: an application of stakeholder theory. Accounting, Organizations and Society 17(6), 595-612.

Saputri, U. T. (2016). Pengaruh Karakteristk Perusahaan, Kinerja Perusahaan dan Intellectual Capital Disclosure Terhadap Underpricing (Studi Empiris: Perusahaan yang Melakukan Penawaran Umum Perdana Periode 2011-2015 di BEI). Skripsi. Universitas Muhammadiyah Yogyakarta.

Satriawan, I. (2016). Pengaruh Pengungkapanmodal Intelektual dalam Prospektus Terhadap Tingkat Underpricing Pada Biaya Modal IPO Perusahaan yang Terdaftar di Bursa Efek Indonesia (Studi Empiris pada Perusahaan yang Melakukan Initial Public Offering di Bursa Efek Indonesia Peri. Jurnal Akuntanika, 2(2), 78-96. 
Wahyusari, A. (2013). Analisis Faktor-Faktor yang Mempengaruhi Underpricing Saham Saat IPO di BEI. Accounting Analysis Journal, 2(4), 386-394.

Witjaksono, L. S. (2012). Analisis Faktor-Faktor Keuangan yang Mempengaruhi Fenomena Underpricing pada Perusahaan Sektor Keuangan yang Terdaftar di Bursa Efek Indonesia 2002-2010. Berkala Ilmiah Mahasiswa Akuntansi, 1(1), 33-37.

Yasa, G. W. (2008). Penyebab Underpricing pada Penawaran Saham Perdana di Bursa Efek Jakarta. Jurnal Akuntansi Bisnis, 3. 1-29.

Yolana, C., \& Martani, D. (2005). Variabel-variabel yang Mempengaruhi Fenomena Underpricing pada Penawaran Saham Perdana di BEJ Tahun 1994-2001. Simposium Nasional VIII Solo, 538-553.

Yustisia, N., \& Roza, M. (2012). Faktor-Faktor yang Memengaruhi Tingkat Underpricing Saham Perdana pada Perusahaan Non-Keuangan Go Public. Media Riset Akuntansi, 2(2), 157 169. 